\title{
UPLIFT PERFORMANCE OF CIRCULAR ANCHOR PLATE EMBEDDED IN CEMENT STABILIZED SAND AND FIBER REINFORCED CEMENT STABILIZED SAND
}

\author{
Avinash $\mathbf{N}^{1}$, Aruna $\mathbf{T}^{2}$ \\ ${ }^{1}$ Assistant Professor, Department of Civil Engineering,CIT College, Mandya,Karnataka, India \\ ${ }^{2}$ Assistant Professor, Department of Civil Engineering, EWIT College, Bangalore, Karnataka, India
}

\begin{abstract}
This project work presents a series of uplift test is conducted in laboratory, using circular anchor plate of diameter 100mm embedded in sand, cement stabilized sand and fiber reinforced cement stabilized sand fill of various $H / D$ ratio $(1,1.5$ and 2$)$. The test was conducted using model tank of diameter 500mm and height 500mm in universal testing machine. The uplift load was finding out by plotting load versus displacement curve of above fill material at various depths. The ultimate load carrying capacity of the fill materials is considered as uplift load. In this study the experimental result gave a clear indication of load carrying capacity, which was increased with the addition cement (4\% of sand) and fibers ( $0.5 \%$ of sand) as reinforcement to the sand fill. In this work we used sand as fill material, as we all know sand is good in friction and non cohesive material. Using cement as binding material and polyester fibers as reinforcement to the sand fill. From the results it was clearly indication that increases in thickness of fill material which increases in the uplift load carrying capacity.
\end{abstract}

Keywords: Uplift capacity; Cement stabilized soil; In situ testing; H/D ratio; Pullout. ****

\section{INTRODUCTION}

The foundations in a transmission line towers, wind mail and buried pipe lines needs to with stand uplift and compressive loadings, when subjected temporary and permanent loading. Permanent loading is caused by self weight of the structure. Temporary loading is caused by wind action in wind mail, cable force in transmission line towers and buoyancy force in buried pipe lines. Temporary load acting on the structure are usually the dominant design loading and produce sudden mechanical failure of the structure, So that the design as to meet both compressive and uplift loading. For this type of foundations requiresground anchors to resist the uplift load coming from the structure.

The study on tension foundation was first started by balla (1961) [1] followed by Meyerhof and Adams (1968) [2] at Nova scotia technical college, Rowe and Davis (1982) [3] at university of Sydney and university of western Ontario. Experimental and field studies on multihelix anchors are much more scarce and are limited to the works of Weikart and Clemence (1987) [4], Mitsch and Clemence (1985)[5], Mooney et al.(1985)[6], Lutenegger et al. (1988)[7], Hoyt and Clemence (1991)[8], and Narasimha Rao et al. (1991) [9].
A few field studies of spread footings bearing on cementtreated layers, all of them concentrating on compressive loadings (Stefanoff et al. 1983 [10]; Consoli et al. 2003, 2009a) [11], have shown a noteworthy increase in the bearing capacity of foundations, looking at the use of soilimprovement techniques. This paper involves an alternative solution for foundation failure due uplift of the foundation. It is formed by providing ground anchor to the foundation system, stabilizing with cement and providing a reinforcement to the foundation soil.

The main objectives of this study are to investigate the following

- The effectiveness of adding cementitious bonding material, for the uplift load carrying capacity of shallow and deep circular anchor plates embedded in sand fill layers of distinct thickness.

- The effectiveness of adding fibers as a reinforced material, for the uplift load carrying capacity of shallow and deep circular anchor plates embedded in sand fill layers of distinct thickness.

- To study the failure mechanism of circular anchor plate embedded in different fill material, considering different embedment depth $(\mathrm{H} / \mathrm{D}=1,1.5$ and 2 where $\mathrm{H}$ is the thickness of a fill material and $\mathrm{D}$ is the diameter of a circular anchor plate). 


\section{MECHANISM}

The project work consist of series of pullout test using circular anchor plate of diameter $0.1 \mathrm{~m}$, it is embedded in uncemented sand, cement stabilized sand and cement stabilized fiber reinforced sand fill. The test is performed for three different embedment depth of $0.1 \mathrm{~m}, 0.15 \mathrm{~m}$ and $0.2 \mathrm{~m}$ of compacted fill at a dry unit weight of $15.4 \mathrm{kN} / \mathrm{m}^{3}$. The sand-cement mixtures were allowed to cure for 7 days before testing, whereas the uncemented sand fill layers did not need any curing period.

\section{MATERIAL}

\subsection{Sand}

I have taken sand as a fill material. The sand which was taken from river is washed in water to remove dirt and mud materials. The various properties of sand are determined by conducting the following tests as per IS 2720 . The sand used is classified as nonplastic, uniform fine sand (SP) as per IS classification system. The various properties of sand as tested in laboratory are listed in table1.

Table 1:Properties of sand

\begin{tabular}{|l|l|}
\hline Specific gravity & 2.83 \\
\hline Grain size distribution & $\begin{array}{l}\text { Fine grain sand } \\
(0.42 \mathrm{~mm} \\
.075 \mathrm{~mm})\end{array}$ \\
\hline D10 to \\
\hline D30 & 0.17 \\
\hline D60 & 0.25 \\
\hline $\begin{array}{l}\text { Coefficient } \\
\text { uniformity }\end{array}$ & 0.35 \\
\hline Coefficient of curvature & 1.05 \\
\hline Maximum dry density & $15.5 \mathrm{kN} / \mathrm{m}^{3}$ \\
\hline Minimum dry density & $13.9 \mathrm{kN} / \mathrm{m}^{3}$ \\
\hline $\begin{array}{l}\text { Angle of internal } \\
\text { friction }\end{array}$ & $35^{\circ}$ \\
\hline
\end{tabular}

\subsection{Cement}

In this project stabilization of sand is done by adding 4 percentage of cement to the total weight of sand taken for all the tests. Properties of cement as per ACC Cement Company are summarized in the table 2 .
Table 2: Properties of cement (as per IS: 12269 - 1987)

\begin{tabular}{|l|l|l|}
\hline $\begin{array}{l}\text { Sl. } \\
\text { No }\end{array}$ & Physical property & $\begin{array}{l}\text { OPC } \\
\text { grade) }\end{array}$ \\
\hline 1 & Standard consistency (\%) & 30 \\
\hline 2 & $\begin{array}{l}\text { Setting time (a) Initial (min) } \\
\text { (b) final (min) }\end{array}$ & $\begin{array}{l}30(\min ) \\
600(\max )\end{array}$ \\
\hline 3 & Compressive strength (Mpa) & \\
& (a) 3 days & 32 \\
& (b) 7 days & 44 \\
& (c) 28 days & 54 \\
\hline & $\begin{array}{l}\text { Fineness } \\
\text { (a) By sieving IS sieve No. 9 }\end{array}$ & 2 \\
& (\%) Brains permeability & 320 \\
\hline 5 & method (m $3 / \mathrm{kg})$ & 3.1 \\
\hline
\end{tabular}

\subsection{Fibers}

In this project stabilization of sand is done by adding 0.5 percentage of fibers to the total weight of sand taken for the tests. Fibers used in this study are polyester (Recron3s) which are synthetic in nature. Properties of fibers as summarized in the table 3 .

Table 3: Properties of fibers

\begin{tabular}{|l|l|l|}
\hline Property & Units & Values \\
\hline Shape & & Triangular \\
\hline Cut length & $\mathrm{mm}$ & $6-12$ \\
\hline Effective diameter & Micron & $20-40$ \\
\hline Specific gravity & & $1.34-2.65$ \\
\hline Melting point & Deg. c & $250-265$ \\
\hline Tensile strength & Gpd & $4-6$ \\
\hline Young's modulus & Mpa & $>5000$ \\
\hline Alkaline strength & & Very good \\
\hline
\end{tabular}

\subsection{Model Tank and Circular Anchor Plate}

Tests were conducted in circular steel tank of diameter $500 \mathrm{~m}$, height $500 \mathrm{~mm}$ and gauge thickness $5 \mathrm{~mm}$ it is made up of mild steel. The tank is large enough to take care of confinement effect as show in "Fig. 1". The circular anchor plate of diameter $100 \mathrm{~mm}$, thickness $10 \mathrm{~mm}$ and it is made of mild steel, placed at the base of the model tank as show in "Fig. 2". 


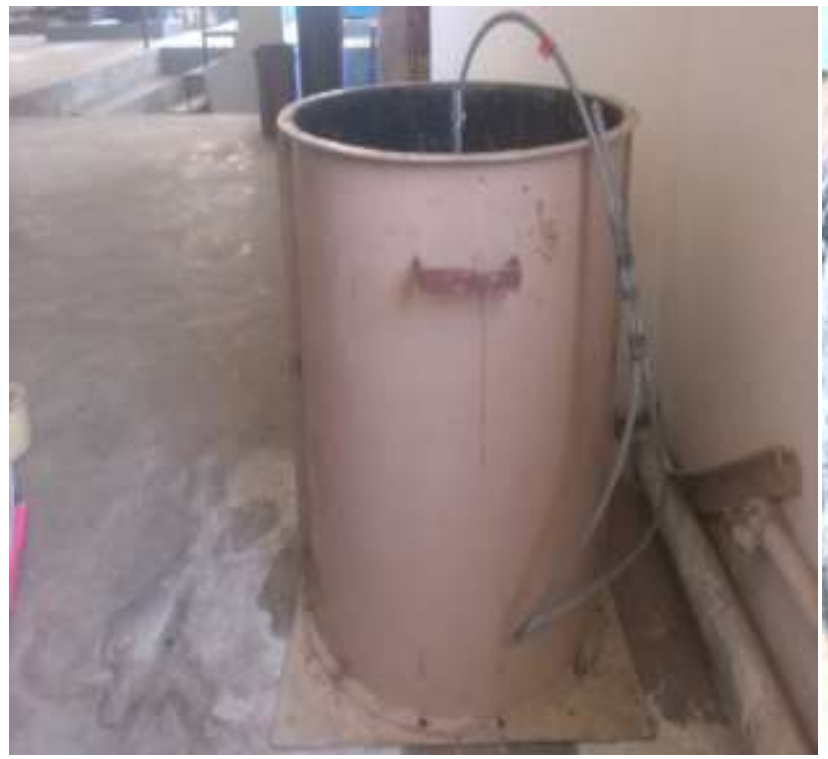

Fig1: Circular steel tank

\section{METHODOLOGY}

To conduct the uplift test following steps are as follows

- The model anchor plate is placed centrally at bottom of mould tank, the mould tank is filled by sand, cement stabilized sand and fiber reinforced cement stabilized sand fill material of distinct embedment depth.

- The tests are conducted for three different fill materials sand, cement stabilized sand and fiber reinforced cement stabilized sand fill material.

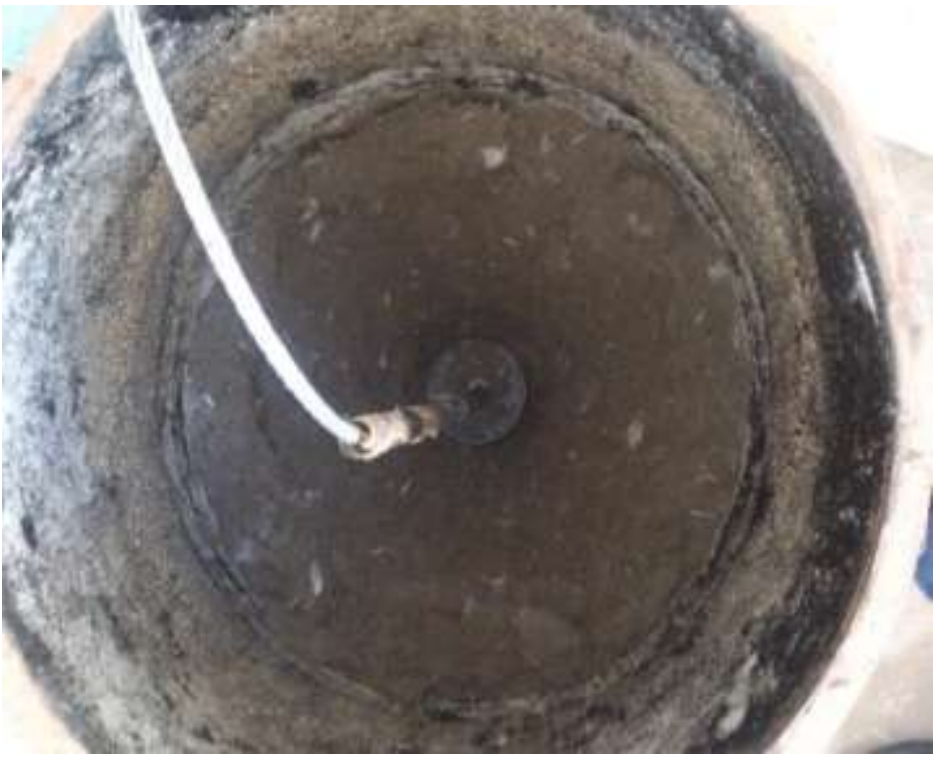

Fig 2:Circular anchor plate

- The H/D ratio (thickness of the fill material to the diameter of the anchor plate), test was conducted for each fill material by varying H/D ratio $1,1.5$ and 2 .

- Suitable arrangements were made to place mould tank in Universal Testing Machine and connecting the anchor plate through steel wire rope to the loading frame, the arrangement was made for carrying out uplift test as per ASTM D1194 (ASTM 1998), the test setup as shown in "Fig. 3"

- Finally load displacement graph were plotted to know the uplift load carrying capacity of fill material.

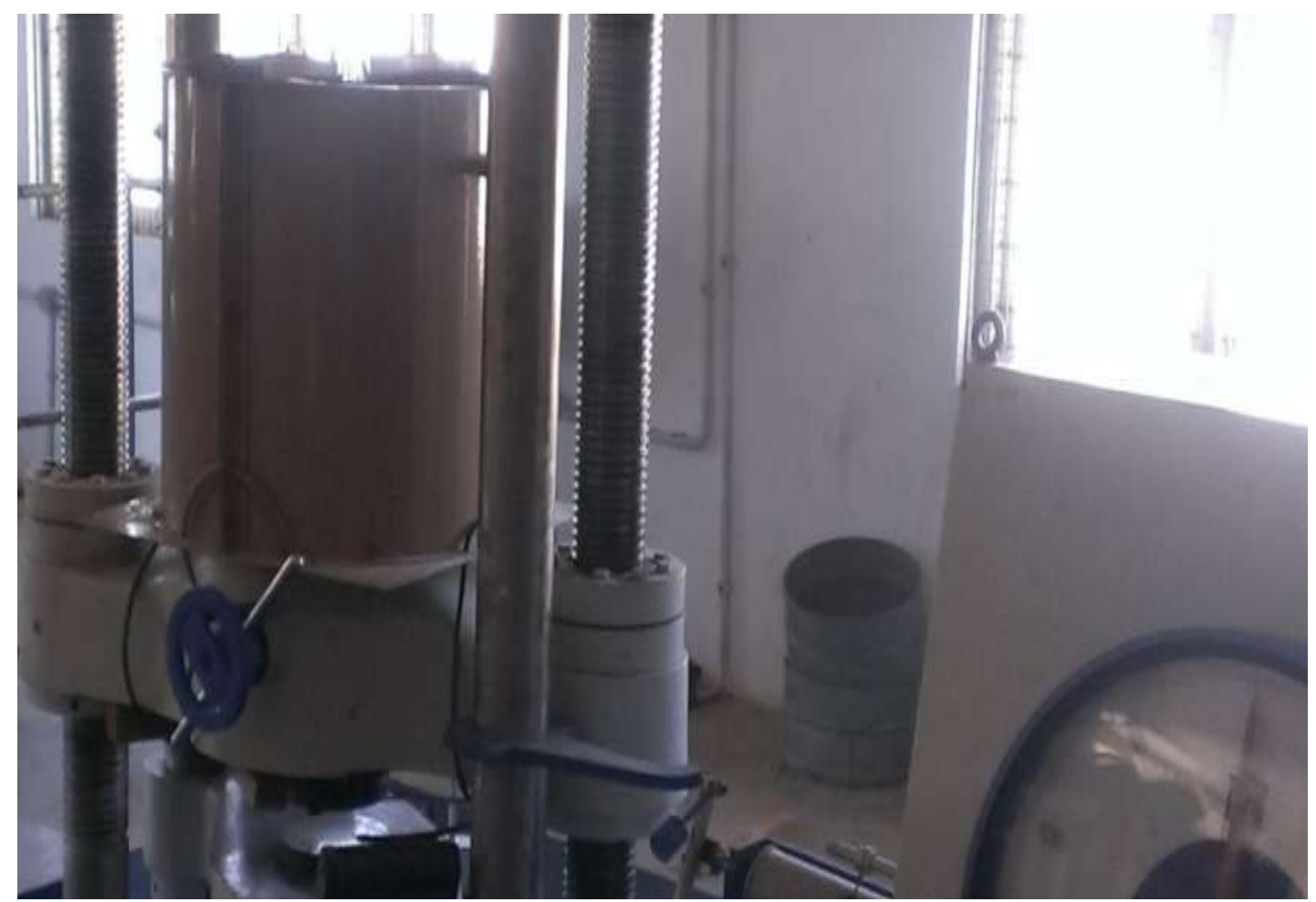

Fig 3:Laboratory uplift test set up 


\section{Cement Stabilized Sand Fill}

Cement stabilized sand fill is prepared by adding $4 \%$ of cement to the total weight of the sand. The mixture of sand and cement are mixed by hand mixing, after mixing $10 \%$ of water is added and thoroughly mix to achieve uniform mixture. To maintain specified dry density $\left(15 \mathrm{kN} / \mathrm{m}^{3}\right)$, the cement stabilized sand fill is compacted in layers of $50 \mathrm{~mm}$ thick up to the desire height (depth or thickness of fill). Then mould containing cement stabilized sand fill is kept 7 days for curing. Similarly for fiber reinforced cement stabilized sand fill is prepared by adding $0.5 \%$ of fibers (recron 3S) to the total weight of the sand. The mixture of sand and cement are mixed by hand mixing, after mixing $10 \%$ of water is added and thoroughly mix to achieve uniform mixture. To maintain specified dry density (15 $\mathrm{kN} / \mathrm{m}^{3}$ ), the fiber reinforced cement stabilized sand fill is compacted in layers of $50 \mathrm{~mm}$ thick up to the desire height (depth or thickness of fill). Then mould containing cement stabilized sand fill is kept 7 days for curing.

\subsection{Test Procedure}

Procedure of the conducted uplift test is briefly explained below

- $100 \mathrm{~mm}$ circular anchor plate is placed centrally at bottom of the circular tank.

- To maintain the required dry unit weight of $15 \mathrm{kN} / \mathrm{m}^{3}$, the weight of sand is taken and $10 \%$ of moisture content is added then it is filled in layers.

- To achieve required dry unit weight $\left(15 \mathrm{kN} / \mathrm{m}^{3}\right)$, it is compacted in three layers up to the required height or depth of the fill layer.

- The prepared mould tank with the sand and the anchor plate is then placed on the loading pad of the universal testing machine.
- The top end of the steel wire rope tied up to the loading frame. Dial gauge is kept on top of the mould to know the displacement of the anchor plate.

- The mould is placed on the adjustable cross head of the universal testing machine, which is fixed to the cross head during loading. So that the mould doesn't lift during loading.

- The universal testing machine is set in tensile movement at an appropriate strain controlled speed to ensure the pullout of the anchor plate.

- Tensile load has applied on the anchor plate and the proving ring readings were observed for different dial gauge readings.

- The test has been carried out till the max load is reached or until failure occurs.

- $\quad$ Above steps are repeated for cement stabilized sand fill and fiber reinforced cement stabilized sand fill material by keeping moisture content and dry unit weight constant for every test.

\section{TEST RESULTS}

The tests were conducted using circular anchor plate of diameter (D) in sand fill of layer thickness $100 \mathrm{~mm}(\mathrm{H})$ compacted at moisture content (10\%) and dry density $\left(15 \mathrm{kN} / \mathrm{m}^{3}\right)$. From the test result load displacement curve was plotted, the ultimate load carrying capacity of sand fill for $\mathrm{H} / \mathrm{D}$ ratio $1,1.5$ and 2 is $3.2 \mathrm{kN}, 3.3 \mathrm{kN}$ and $3.5 \mathrm{kN}$ as shown in "Fig. 4". Similarly for cement stabilized sand fill for H/D ratio $1,1.5$ and 2 is $4.5 \mathrm{kN}, 8 \mathrm{kN}$ and $13 \mathrm{kN}$ as shown in "Fig. 5" and for fiber reinforced cement stabilized sand fill for $\mathrm{H} / \mathrm{D}$ ratio $1,1.5$ and 2 is $5 \mathrm{kN}, 9.2 \mathrm{kN}$ and $15.5 \mathrm{kN}$ as shown in "Fig. 6"

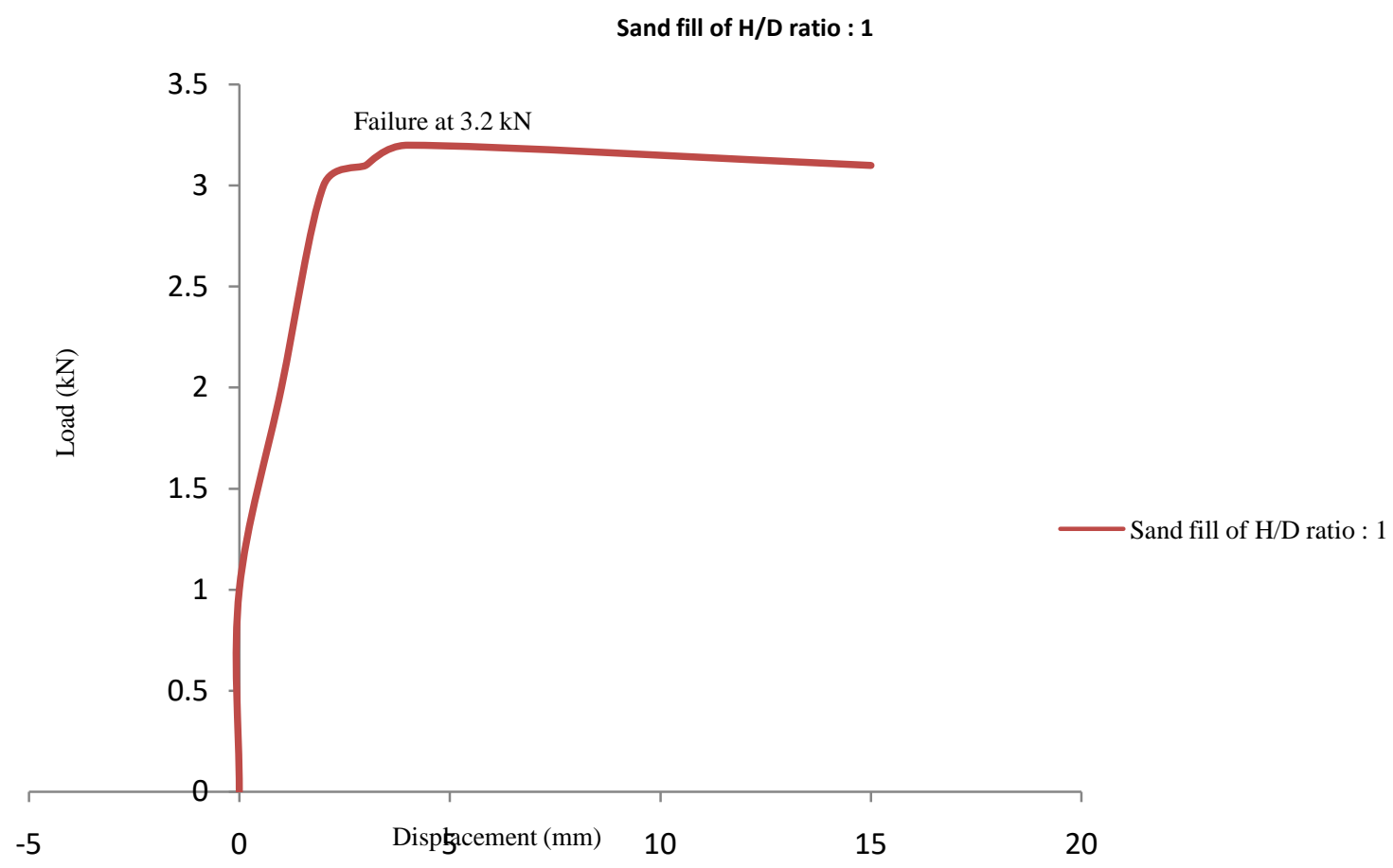

(a) 


\section{Sand fill of H/D ratio : 1.5}

failure at : $3.3 \mathrm{kN}$

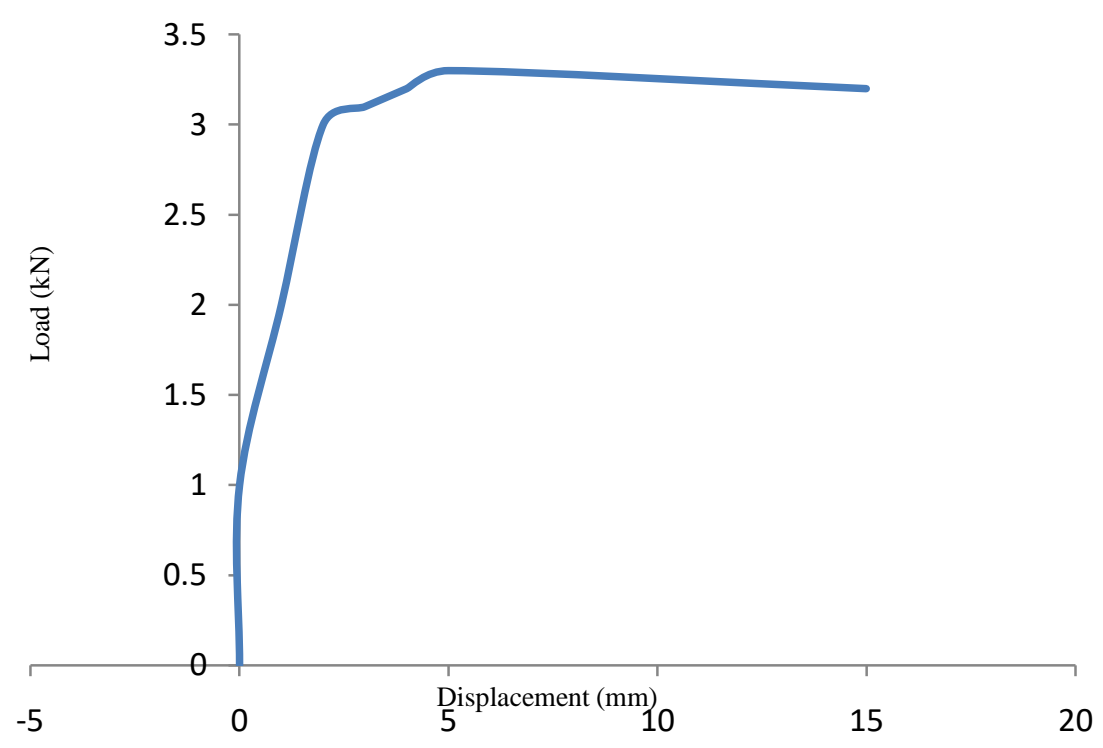

(b)

Sand fill of $H / D$ ratio : 2

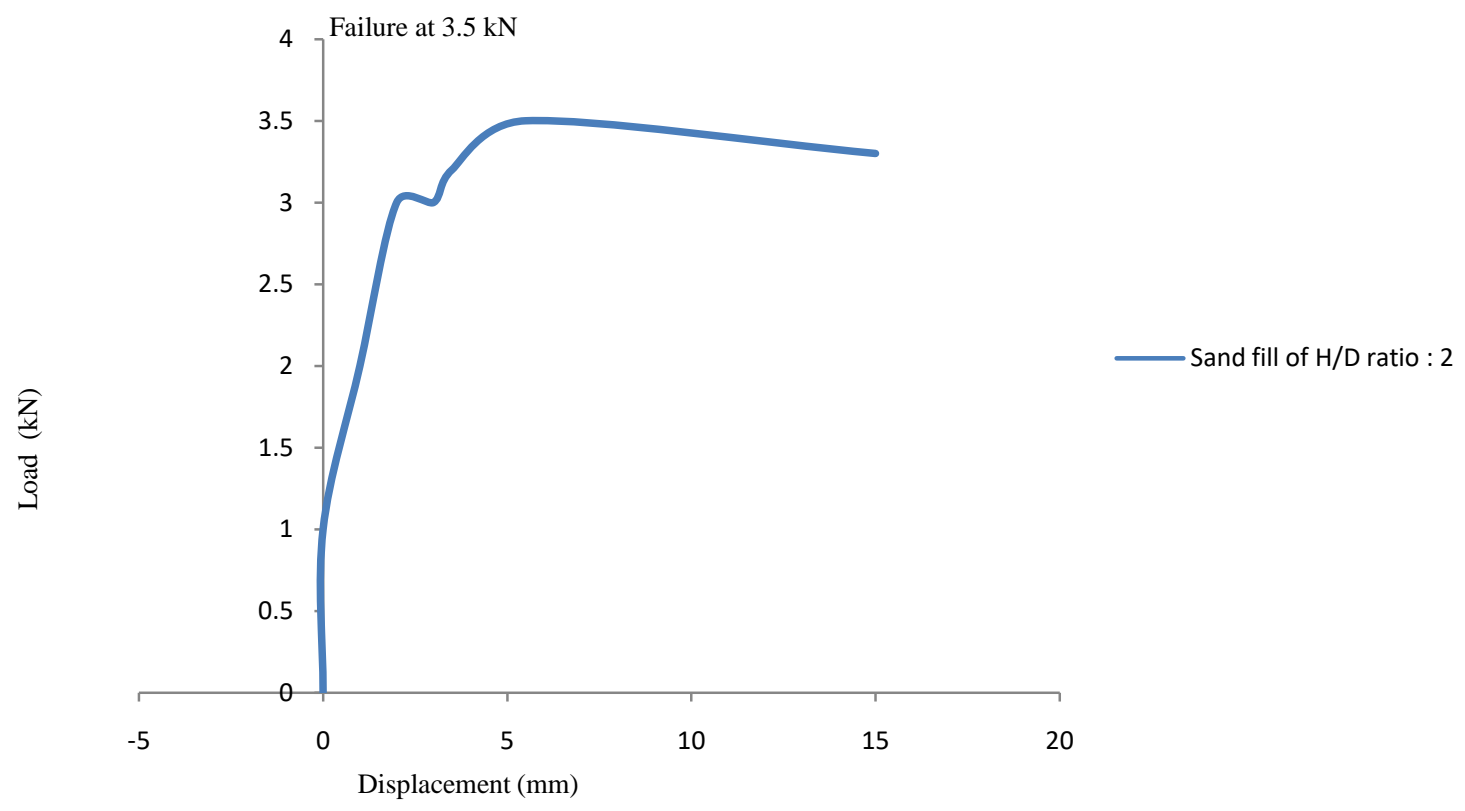

(c)

Fig 4:Load displacement curve for sand fill of (a) H/D ratio 1 (b) H/D ratio 1.5 (c) H/D ratio 2 
Cement stabilized sand fill of H/D ratio : 1

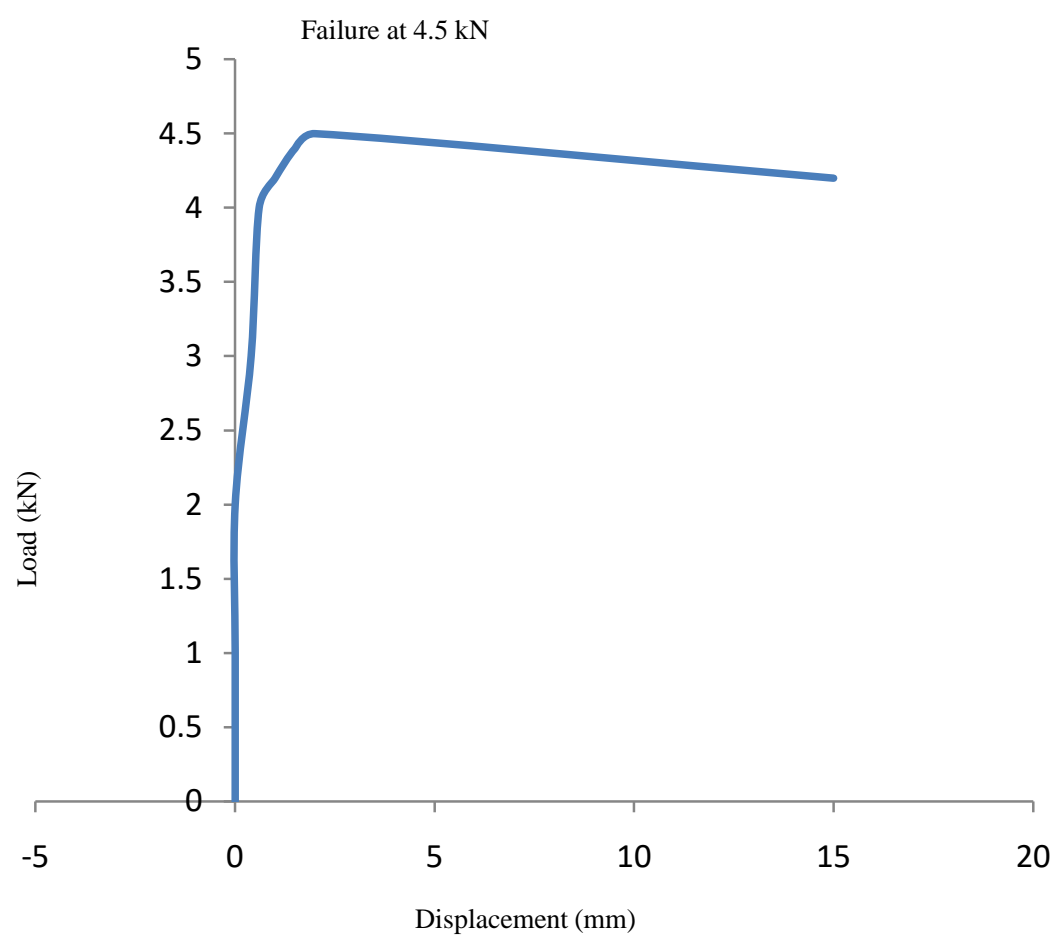

cement stabilized sand fill of H/D ratio : 1

(a)

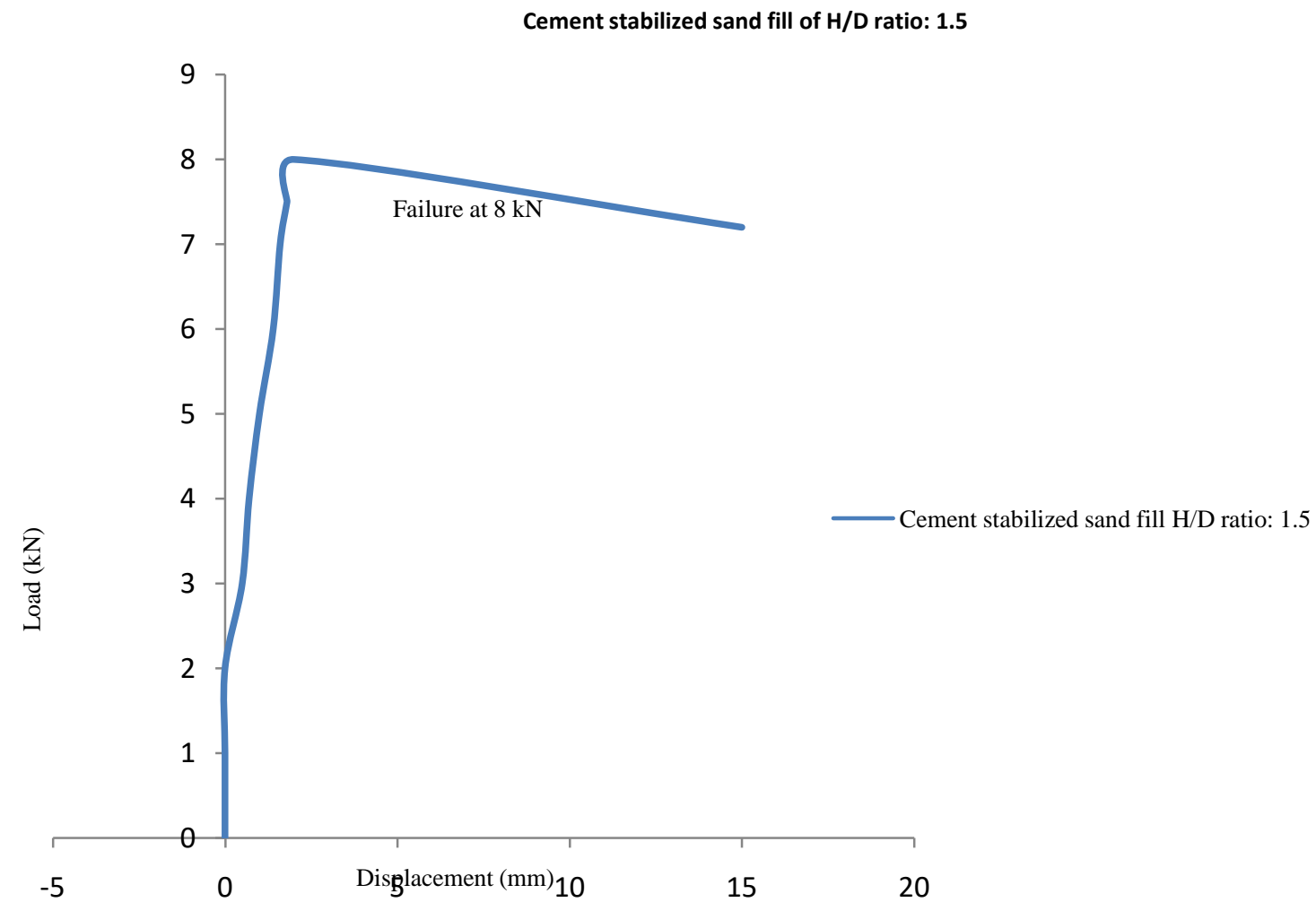

(b) 


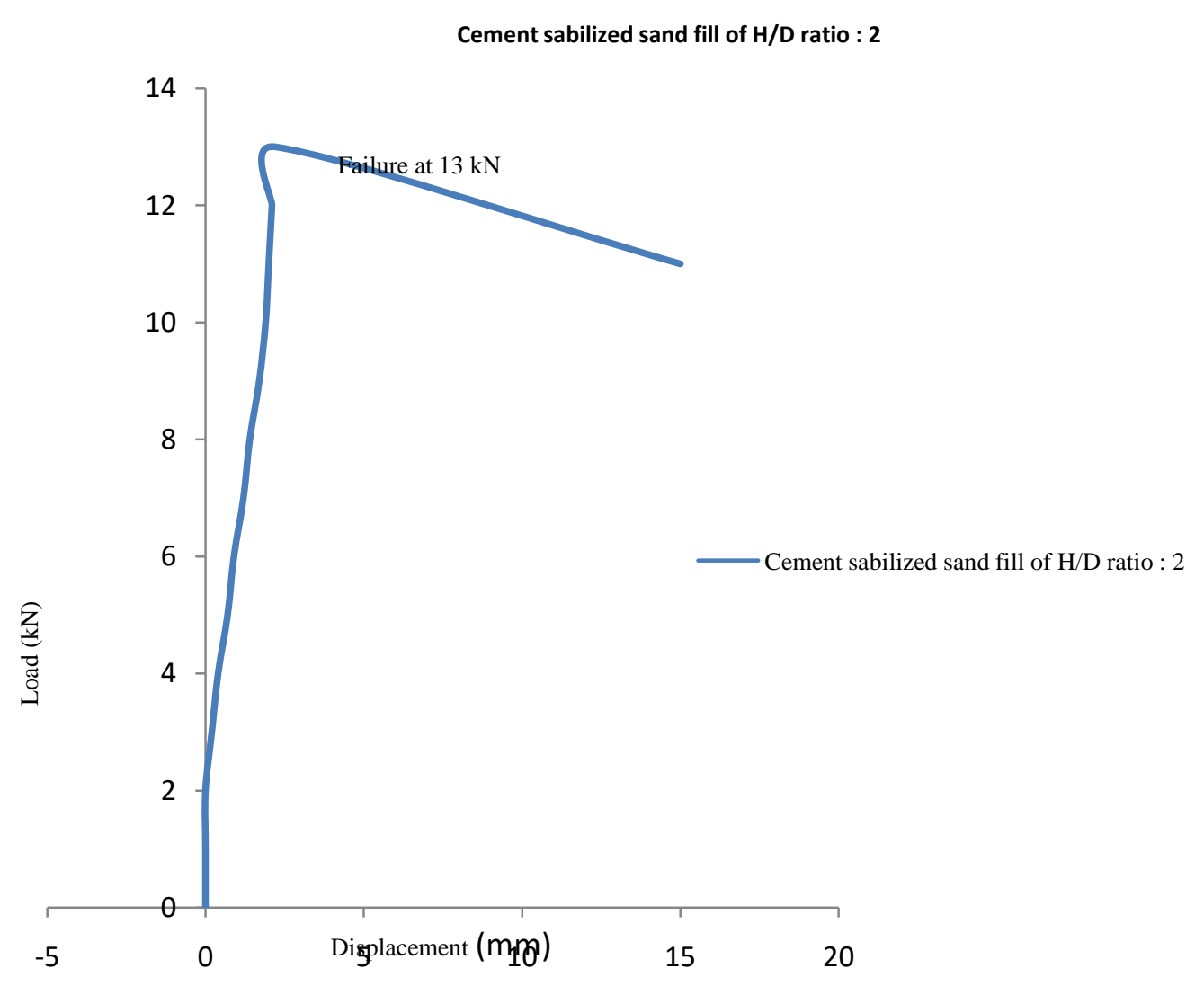

(c)

Fig 5:Load displacement curve for cement stabilized sand fill of (a) H/D ratio 1 (b) H/D ratio 1.5 (c) H/D ratio 2

Fiber reinforced cement stabilized sand of $\quad H / D$ ratio : 1

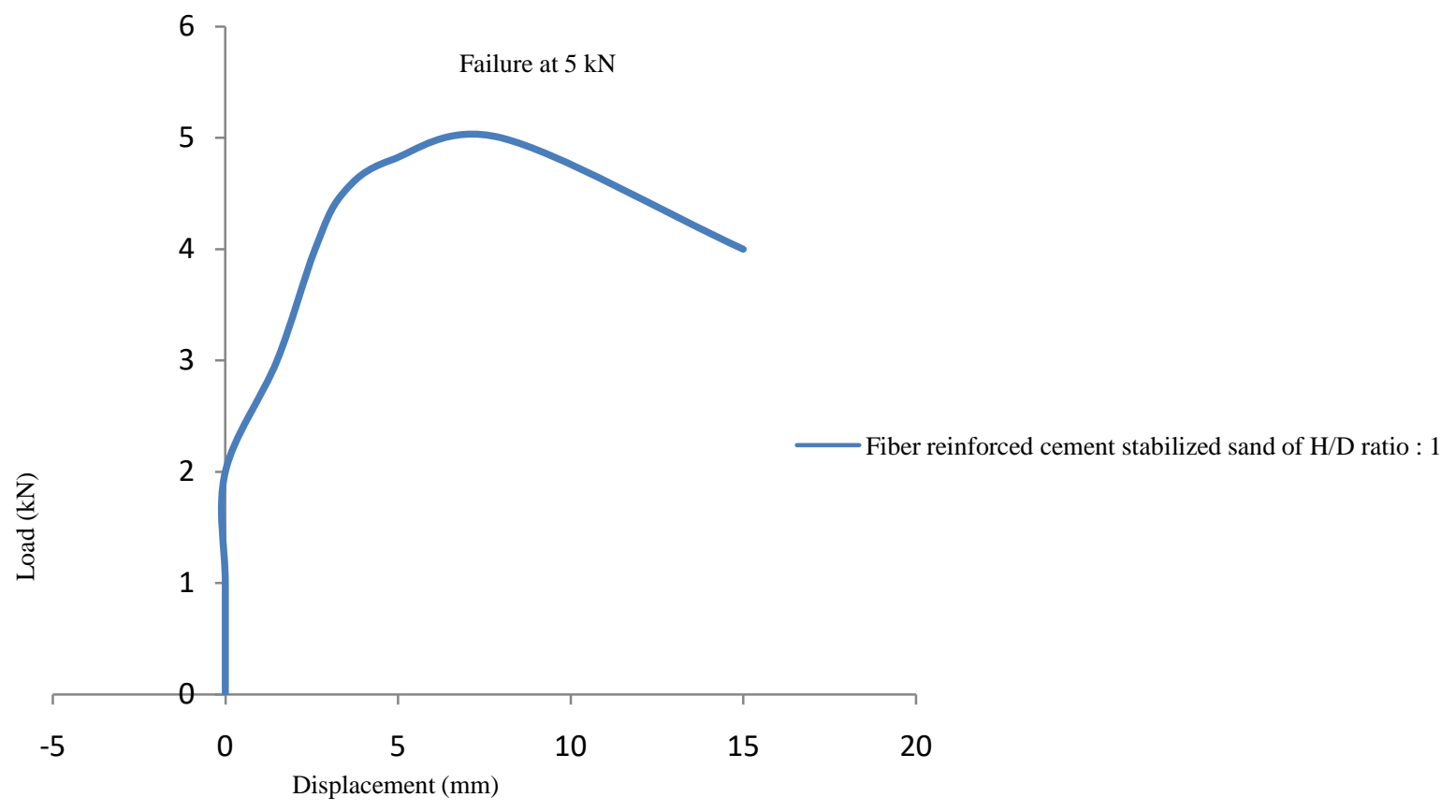

(a) 


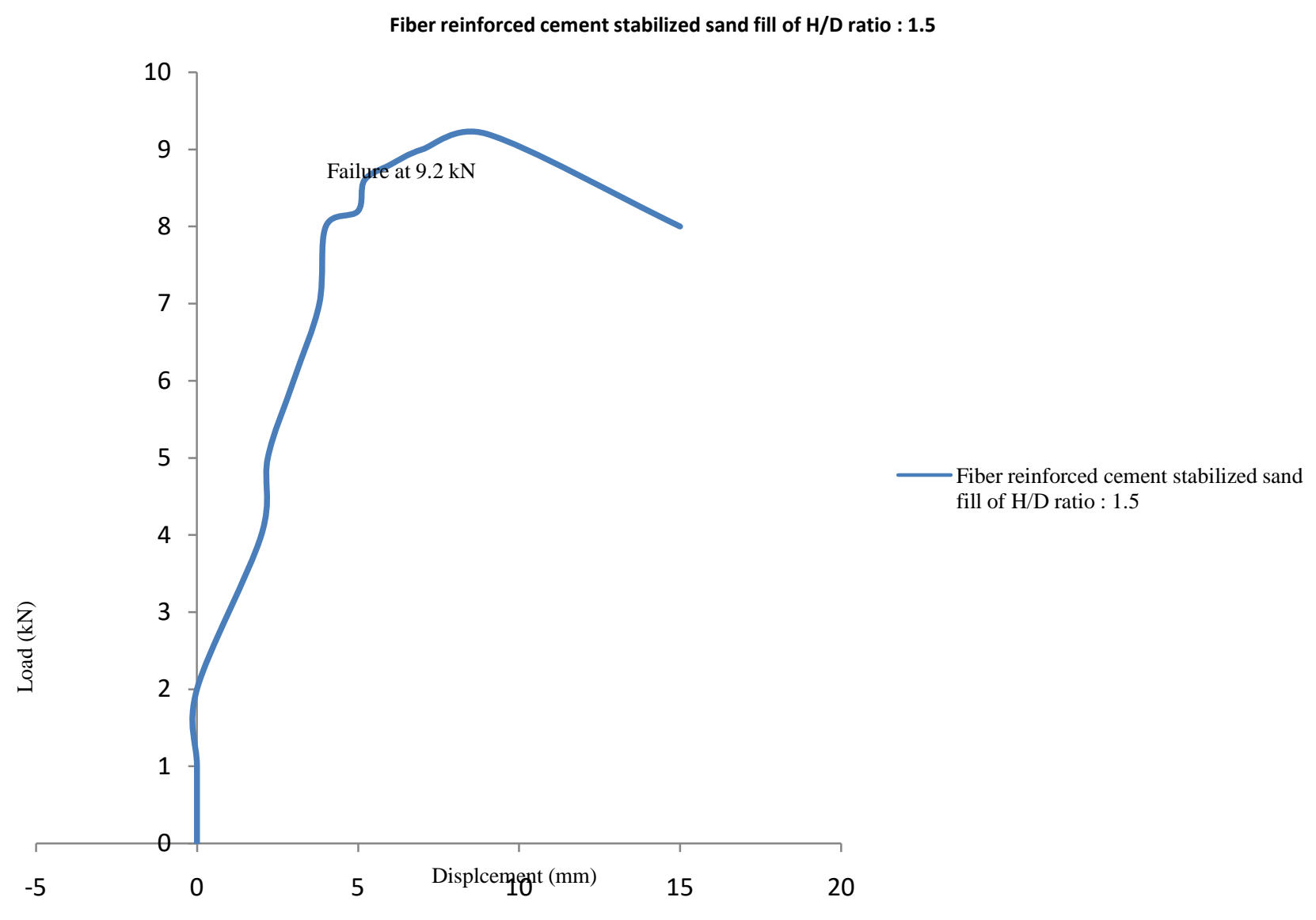

(b)

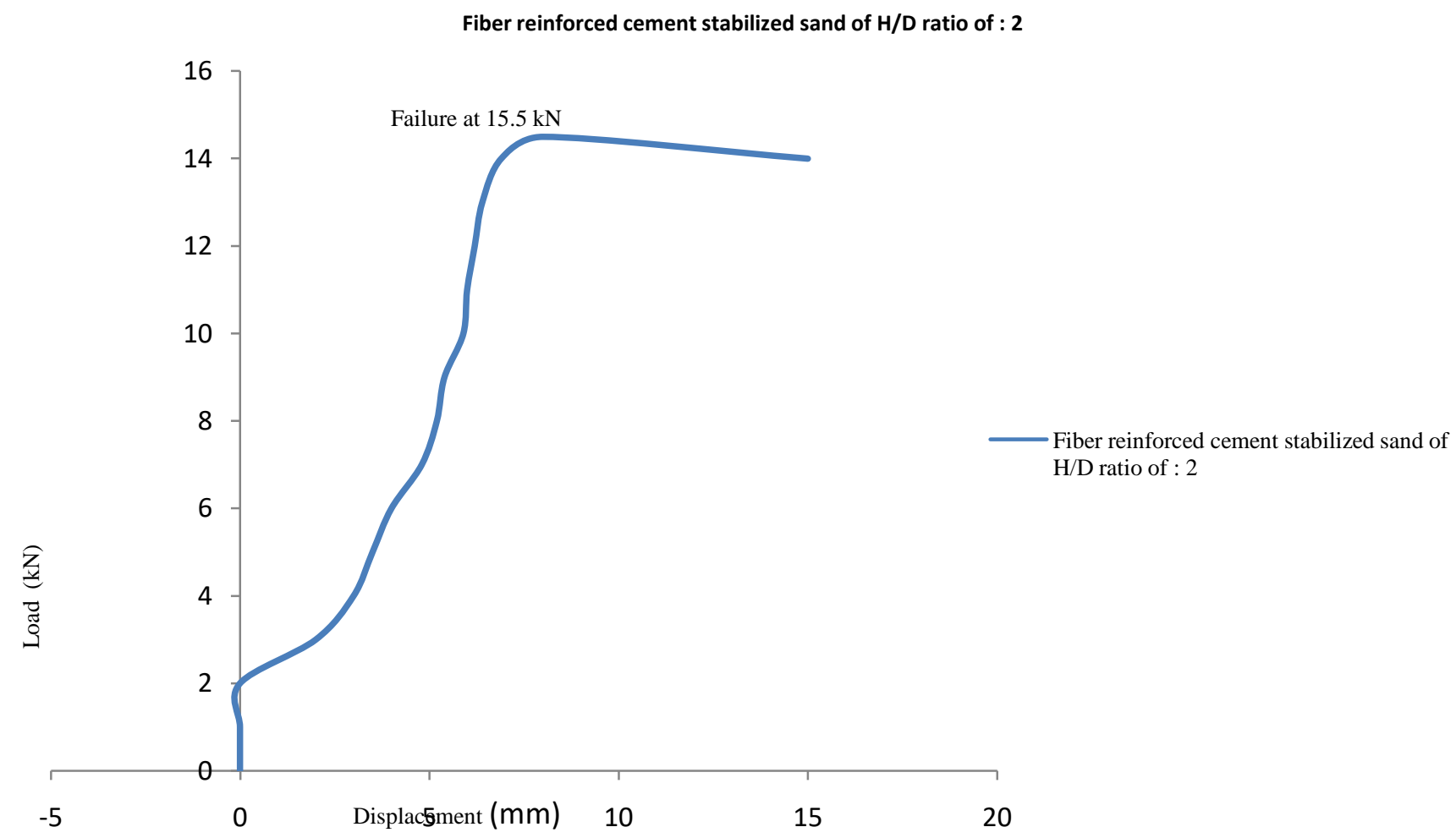

(c)

Fig 6:Load displacement curve for fiber reinforced cement stabilized sand fill of (a) H/D ratio 1 (b) H/D ratio 1.5 (c) H/D ratio 2 


\section{RESULTS AND DISCUSSIONS}

In this project total 12 tests were conducted under different conditions. Out of 12 tests, 3 tests were conducted for elastic behavior of sand, cement stabilized sand and fiber reinforced cement stabilized sand fill materials. Out of remaining 9 tests, 3 tests were conducted to know the uplift load carrying capacity of sand fill material by varying H/D ratio (1, $1.5 \& 2)$, similarly 3 tests for cement stabilized sand and 3 tests for fiber reinforced cement stabilized sand, the various test results are tabulated as tabulated in table (4). The ultimate pull out load or failure load for this study is defined as the load at which the fill material fails by cracking or it is the maximum load at which loaddisplacement curve reaches peak point.

Table 4:Test results

\begin{tabular}{|c|c|c|c|c|c|c|}
\hline $\begin{array}{l}\text { Fill } \\
\text { material }\end{array}$ & $\begin{array}{l}\begin{array}{l}\text { Anchor } \\
\text { plate dia } \\
(\mathbf{m m})\end{array}\end{array}$ & $\begin{array}{l}\text { Moisture } \\
\text { Content } \\
\text { (\%) }\end{array}$ & $\begin{array}{l}\text { Dry density } \\
\left(\mathbf{k N} / \mathbf{m}^{3}\right)\end{array}$ & $\begin{array}{l}\text { Embedment } \\
\text { Depth } \\
(\mathbf{m m})\end{array}$ & H/D ratio & $\begin{array}{l}\text { Ultimate } \\
\text { Uplift } \\
\text { load } \\
(\mathbf{k N})\end{array}$ \\
\hline \multirow{3}{*}{ Sand } & \multirow{3}{*}{100} & \multirow[t]{3}{*}{10} & \multirow{3}{*}{15} & 100 & 1 & 3.2 \\
\hline & & & & 150 & 1.5 & 3.3 \\
\hline & & & & 200 & 2 & 3.5 \\
\hline \multirow{3}{*}{$\begin{array}{l}\text { Cement } \\
\text { stabilized } \\
\text { sand }\end{array}$} & \multirow[t]{3}{*}{100} & \multirow[t]{3}{*}{10} & \multirow[t]{3}{*}{15} & 100 & 1 & 4.5 \\
\hline & & & & 150 & 1.5 & 8 \\
\hline & & & & 200 & 2 & 13 \\
\hline \multirow{3}{*}{$\begin{array}{l}\text { Fiber } \\
\text { reinforced } \\
\text { cement } \\
\text { stabilized } \\
\text { sand }\end{array}$} & \multirow[t]{3}{*}{100} & \multirow[t]{3}{*}{10} & \multirow[t]{3}{*}{15} & 100 & 1 & 5 \\
\hline & & & & 150 & 1.5 & 9.2 \\
\hline & & & & 200 & 2 & 15.5 \\
\hline
\end{tabular}

From the above table (4), it was clearly observed that increase in the load carrying capacity with increase in the embedment depth or thickness of fill material. From the "Fig. 7" shows that higher the H/D ratio higher be the load carrying capacity, The load versus H/D ratios was plotted for all the fill material, in the "Fig. 7" it was clearly shows that Fiber reinforced cement stabilized sand fill which carries higher uplift load compare to cement stabilized sand fill, similarly for cement stabilized sand fill carries more load compare to sand fill for all H/D ratios.

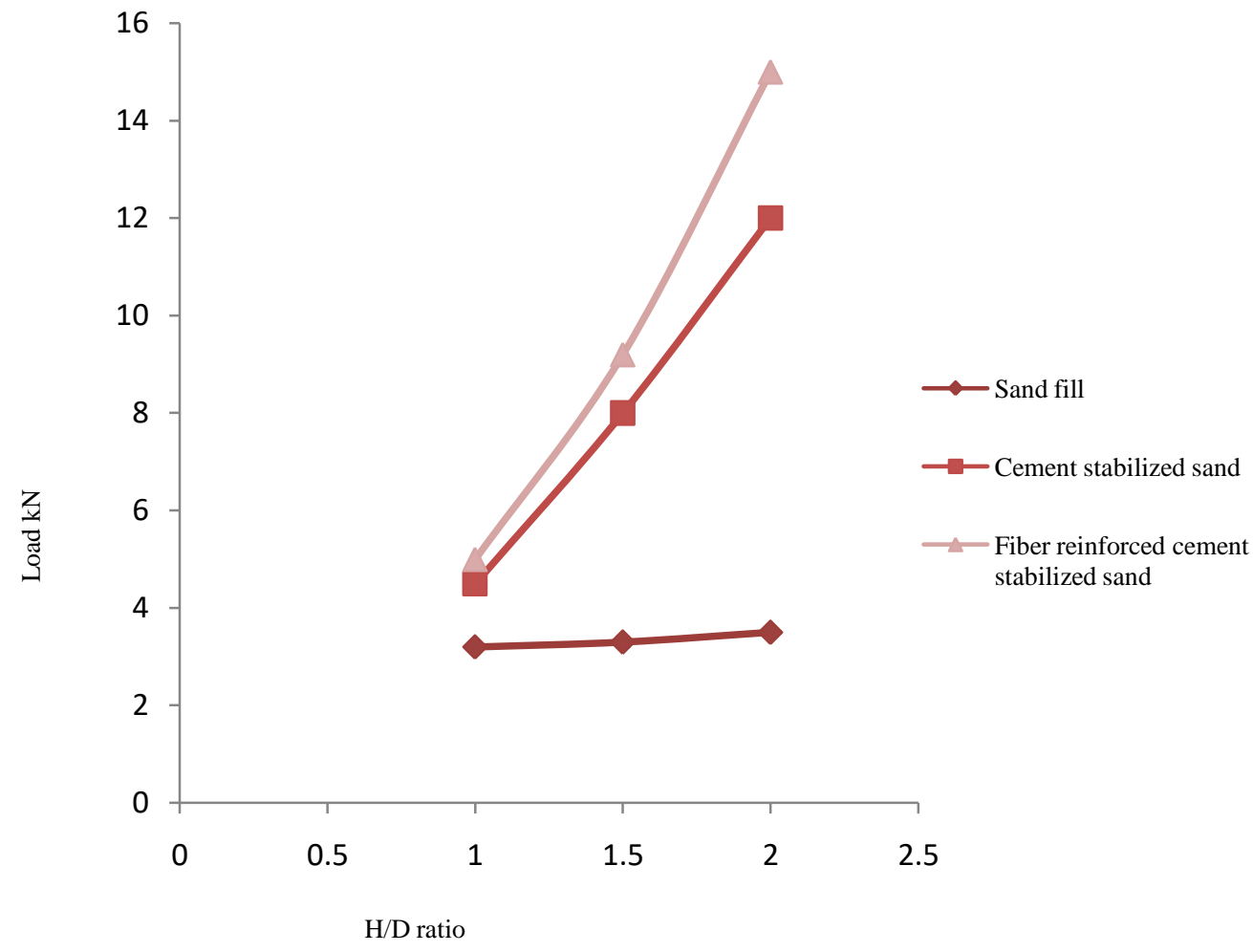

Fig 7:Load verses H/D ratios for sand, cement and fiber reinforced cement stabilized sand fill material 
From the "Fig. 7" shows that higher the H/D ratio higher be the load carrying capacity, The load versus H/D ratios was plotted for all the fill material as shown in the "Fig. 7" it was clearly showing that Fiber reinforced cement stabilized sand fill which carries higher uplift load compare to cement stabilized sand fill, similarly for cement stabilized sand fill carries more load compare to sand fill for all H/D ratios.

\subsection{Failure Mechanism}

From the experimental work for shallow anchor the failure envelop reaches the ground surface, forming truncated cone type of failure in fill material as shown in fig (8) and on surface circular concentric cracks are observed. The failure pattern is same as theoretical failure mechanism in introduction part. For deep anchor $H / D$ ratio $\geq 2$, the failure envelope does not reaches ground surface. The failure is formed around the anchor plate and finally it comes through the center of the cable towards top of the ground surface forming the cracks around the cable. The cracks initially starts from the center of the cable and move out wards or away from the cable, the size of the cracks are large around the cable and starts decreasing when moving away from the center of the cable as shown in "Fig. 8".

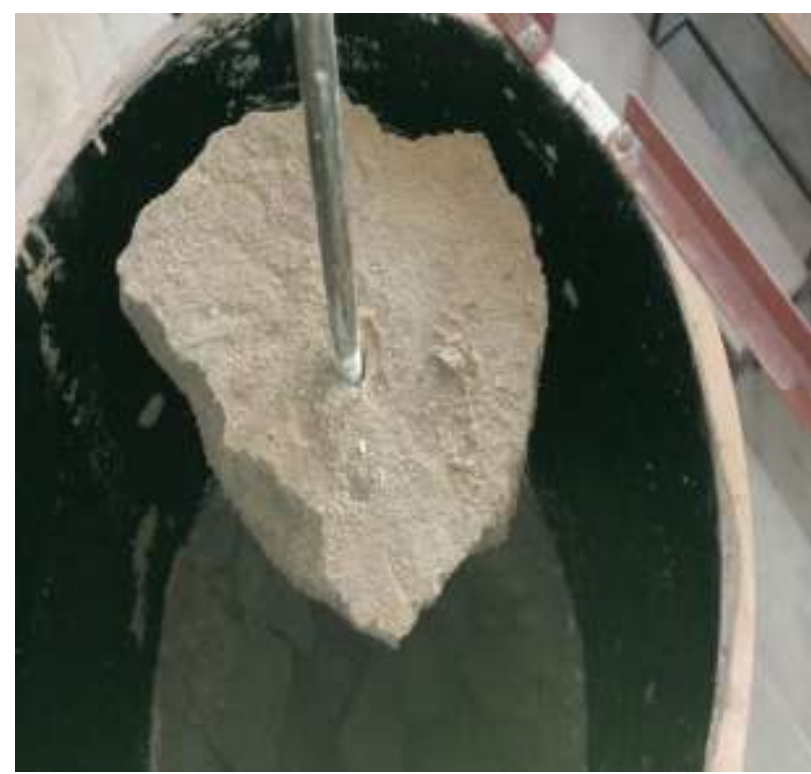

(a)(b)

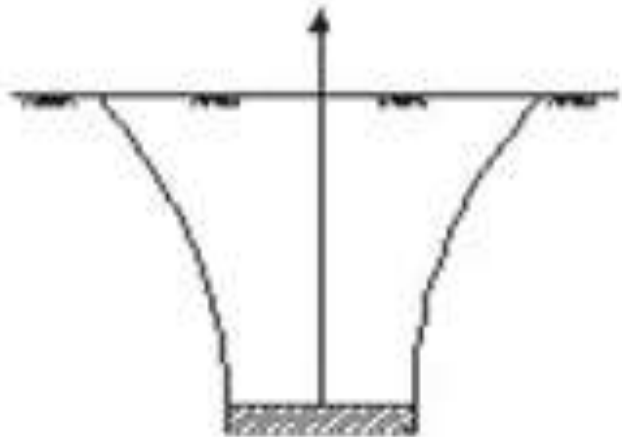

Fig 8: Shallow anchor (a) Experimental failure at H/D ratio 1 (b) Theoretical failure at H/D ratio $<2$

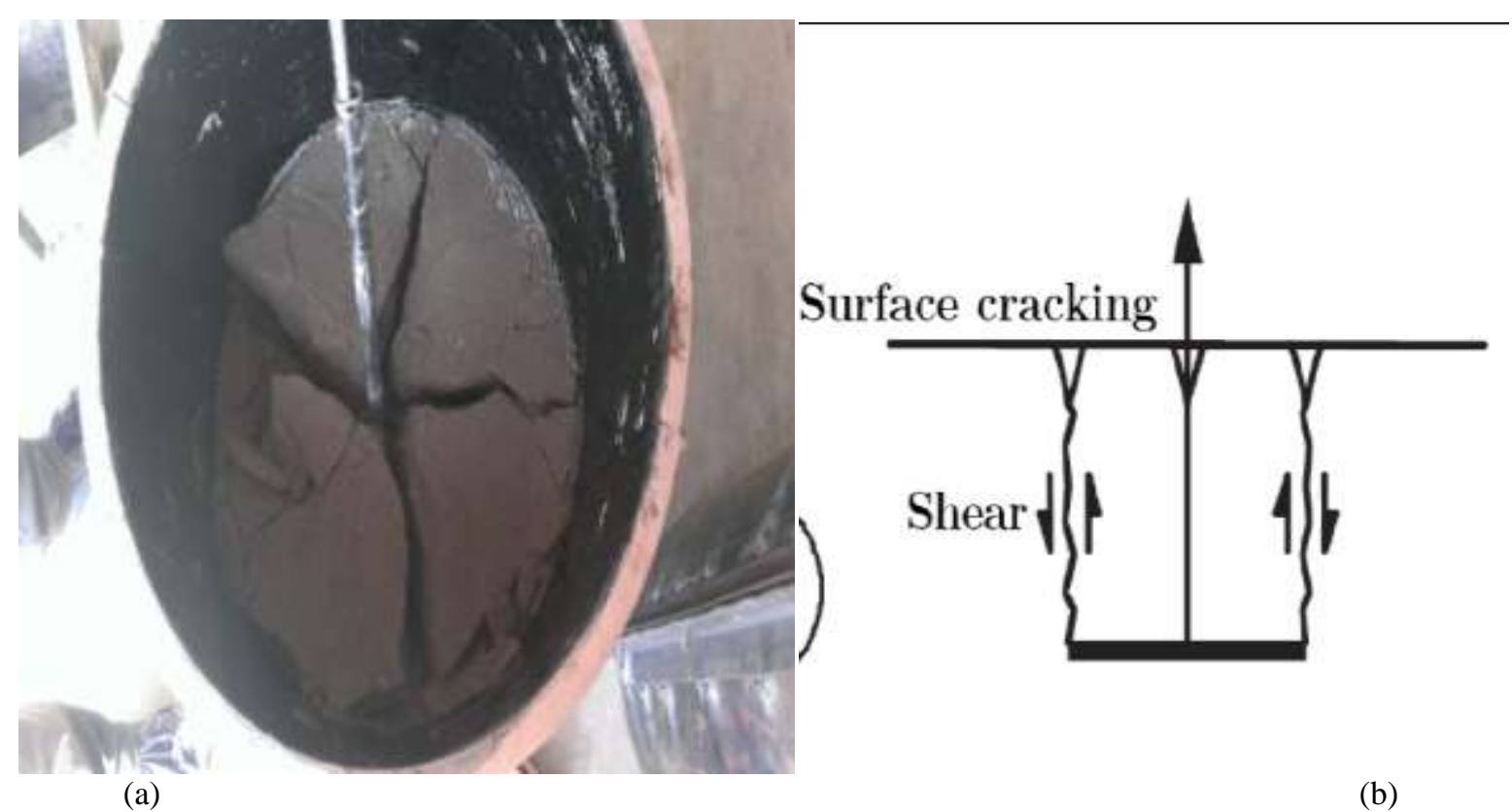

Fig 9: Deep anchor (a) Experimental failure at $H / D$ ratio $=2$ (b) Theoretical failure at H/D ratio $\geq 2$ 


\section{CONCLUSION}

The outcomes from this work can be summarized as follows

- The uplift load carrying capacity of anchor plate embedded in sand, cement and fiber reinforced cement stabilized sand fill increases with increse in the embedment depth.

- The uplift load carrying capacity increased due to the addition of cement $(4 \%)$ and fibers $(0.5 \%)$ to the sand fill material for the entire studied H/D ratio 1, 1.5 and 2 .

- Distinct failure patterns were observed at deep and shallow anchor plate embedded in sand, cement and fiber reinforced cement stabilized sand fill.

- The ductile behavior was observed in fiber reinforced cement stabilized sand fill

\section{REFERENCES}

[1] Balla, A. (1961). "The resistance to breaking out mushroom foundations for pylons." Proc., 5th Int. Conf. on Soil Mechanics and Foundation Engineering, Vol. 1, Paris, 569-576.

[2] Meyerhof and Adams, J. I. (1968). "Ultimate uplift capacity of foundations." Can. Geotech. J., 5(4), 225244. Mitsch, M. P., and Clemence, S. P. (1985). "Uplift capacity of helix anchors in sand." Proc., ASCE Convention, Uplift Behavior of Anchor Foundations in Soil, ASCE, New York, 26-47.

[3] Rowe, R. K., and Davis, E. H. (1982a). "The behavior of anchor plates in clay." Geotechnique, 32(1), 9-23.

[4] Weikart, A. M., and Clemence, S. P. (1987). "Helix anchor foundations- Two case histories."Foundations for transmission line towers (GSP 8), ASCE, New York, 72-80.

[5] Mitsch, M. P., and Clemence, S. P. (1985). "Uplift capacity of helix anchors in sand." Proc., ASCE Convention, Uplift Behavior of Anchor Foundations in Soil, ASCE, New York, 26-47.

[6] Mooney, J. S., Adamczak, S. J., and Clemence, S. P. (1985). "Uplift capacity of helix anchors in clay and silt." Proc.,ASCE Convention, Uplift Behavior of Anchor Foundations in Soil, ASCE, New York, 4872.

[7] Lutenegger, A. J., Smith, B. L., and Kabir, M. G. (1988). "Use of in situ tests to predict uplift performance of multihelix anchors." Special topics in foundations (GSP 16), ASCE, New York, 93-110.

[8] Hoyt, R. M., and Clemence, S. P. (1991). "Uplift capacity of helical anchors in soil." Proc., 12th Int. Conf. on Soil Mechanics and Foundation Engineering [Comptes Rendus du Congres International de Mecanique des Sols et des Travaux de Fondations], Vol. 2, A. A. Balkema Publishers, Rotterdam, Netherlands, 1019-1022.

[9] Narasimha Rao, S., Prasad, Y. V. S. N., and Veeresh, C. (1993). "Behavior of embedded model screw anchors in soft clays." Géotechnique, 43(4), 605-614.
[10] Stefanoff, G., Jellev, J., Tsankova, N., Karachorov, P., and Slavov, P. (1983). "Stress and strain state of a cement-loess cushion." Proc., 8th European Conf. of Soil Mechanics and Foundation Engineering, A. A. Balkema, Rotterdam, Netherlands, 811-816.

[11] Consoli, N. C., Vendruscolo, M. A., and Prietto, P. D. M. (2003). "Behavior of plate load tests on soil layers improved with cement and fiber." J. Geotech. Geoenviron. Eng., 129(1), 96-101. 